\title{
Kaposi's sarcoma associated herpes virus (KSHV/HHV 8): epidemiology, molecular biology and tissue distribution
}

\author{
J J O’Leary, M M Kennedy, J O’D McGee
}

\section{Introduction}

Although first described in 1872, Kaposi's sarcoma remains a neoplasm of uncertain histiogenesis. ${ }^{1}$ The lesion is considered by some experts to be a vascular neoplasm and by others, a reactive vasoformative condition. Currently, the debate still rages over the precise cell of origin of Kaposi's sarcoma-that is, whether it is of lymphatic or true endothelial cell origin.

Clinically, Kaposi's sarcoma is often multifocal and the spindle cells of these individual lesions have been shown to be clonal in origin. ${ }^{2}$ It is also known that Kaposi's sarcoma lesions can regress spontaneously, especially when immunosuppressive treatment is discontinued, thereby suggesting that the growth of Kaposi's sarcoma is controlled by host factors. In addition, at least one group has observed regression of Kaposi's sarcoma lesions when patients are treated with the anti-herpes viral drug Foscarnet. ${ }^{3}$ The role of cytokines has also been explored, as has the contribution of the HIV Tat protein which may act in a synergistic manner (see later).

Epidemiological evidence suggests an infectious aetiology for Kaposi's sarcoma, which is supported by the clustering of the disease in well-defined populations (men with AIDS and homosexual men) and its relation to immunosuppression. ${ }^{4}$ Many agents have been investigated as possible aetiological factors, including human papilloma virus, cytomegalovirus and Epstein-Barr virus (EBV), but no convincing association has ever been established.

\section{Kaposi's sarcoma associated herpes virus (KSHV)/human herpes virus type 8 (HHV8)}

In 1994, Chang et al documented the presence of a previously undescribed virus in Kaposi's sarcoma tissue samples (fig 1). This Kaposi's sarcoma associated herpes virus (HHV8) was discovered using representation difference analysis which permits the discrimination of DNA sequences which are present in tumour tissue from ones that are absent in normal DNA from the same patient. The newly described virus shows similarity to two other gamma herpes viruses-herpes virus saimiri (HVS) and EBV. ${ }^{6}$

Viral genetic analysis demonstrates that the agent is a gamma II herpes virus (genus Rhadinovirus) and is the first member of this genus known to infect humans (fig 2). HHV8 has been partially sequenced recently and many regions show sequence homology at the DNA level to both EBV and HVS.

\section{Tissue distribution of $\mathrm{HHV8}$}

Using PCR, HHV8 is found in more than $90 \%$ of HIV associated Kaposi's sarcoma lesions as well as in classic Kaposi's sarcoma, and endemic and post-transplant associated Kaposi's sarcoma. ${ }^{7-12}$ HHV8 has also been described in two AIDS related lymphoproliferative disorders: body cavity based lymphomas (BCBL or primary effusion lymphomas) and multicentric Castleman's disease (MCD) which itself is related to the development of Kaposi's sarcoma. ${ }^{13} 14$

BCBLs are a unique group of nonHodgkin's lymphomas, largely confined to HIV
Nuffield Department of Pathology and Bacteriology, University of Oxford, Oxford OX3 9DU J J O'Leary $M$ M Kennedy J O'D McGee

Correspondence to: Dr J J O'Leary.

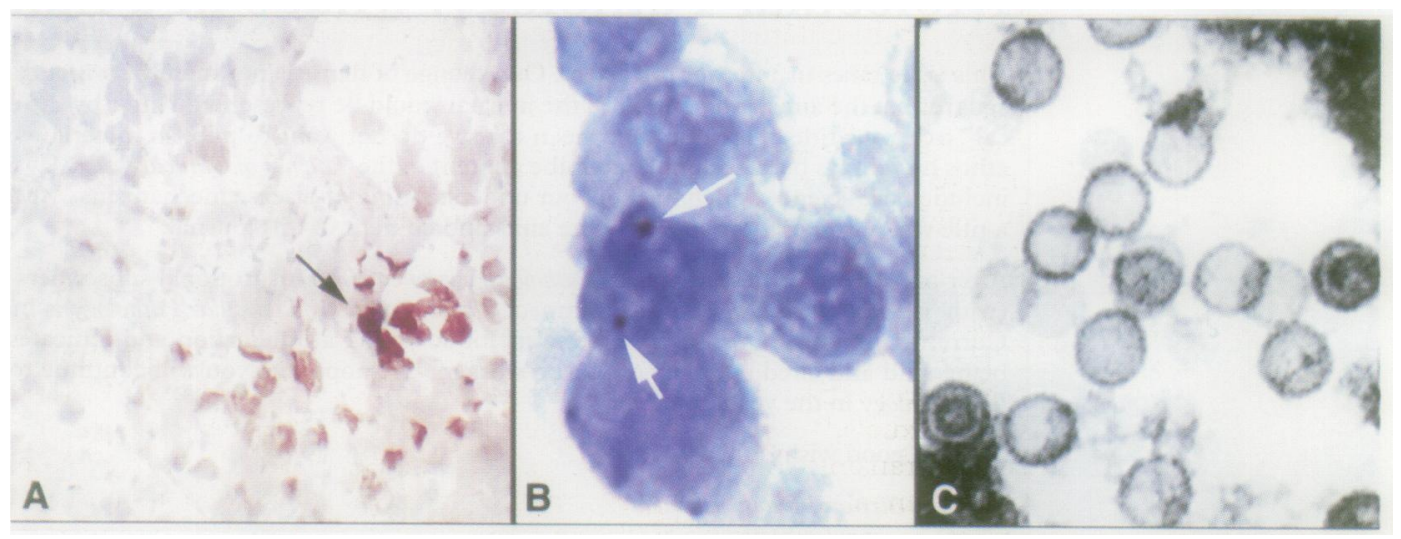

Figure 1 (A) HHV8 amplicons in Kaposi's sarcoma (KS) identified by PCR ISH, showing positive signals in KS spindle cells (arrow). (B) HHV8 identified by non-isotopic in situ hybridisation (NISH) in the BCP-1 cell line derived from a BCBL showing two discrete intranuclear signals (arrows). (C) HHV8 virions identified in a BCBL derived cell line showing the characteristic herpes-like viral particles. 
Gamma herpes viruses

Rhadinovirus

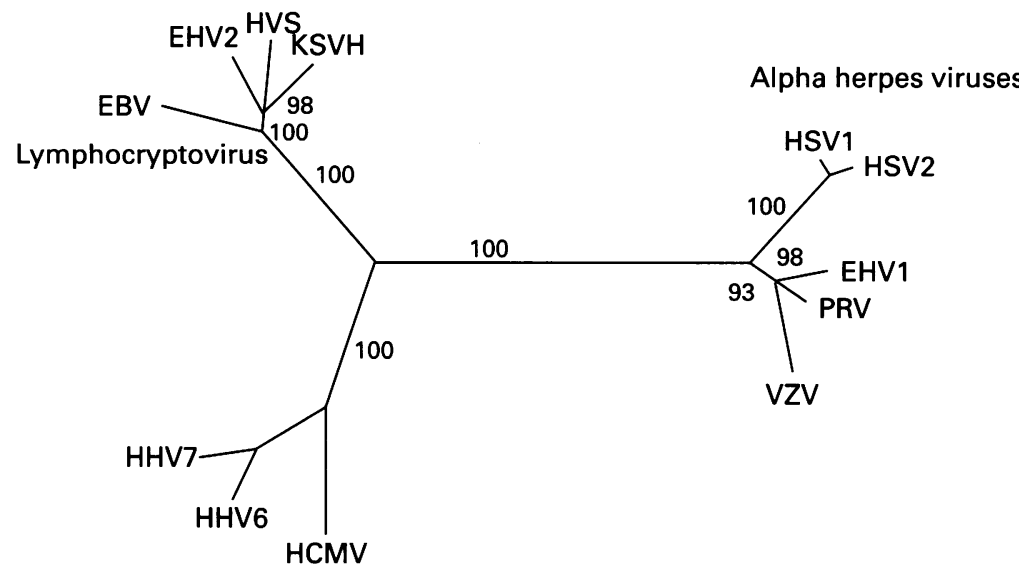

Beta herpes viruses

Figure 2 Phylogenetic tree of HHV8 based on comparison of amino acid sequences of the major capsid protein of HHV8 (adapted from Moore et al).

positive individuals. ${ }^{1315}$ These lymphomas seem to represent a distinct subgroup of B-cell non-Hodgkin's lymphomas with a strikingly similar clinical, morphological, immunophenotypic, and molecular genetic profile that readily distinguishes them from the vast majority of AIDS related lymphomas. These lymphomas exclusively involve pleuro-pericardial or abdominal cavities, or both, as lymphomatous effusions, usually in the absence of any identifiable tumour mass in lymph nodes or mucosa associated lymphoid tissues. They have an indeterminate immunophenotype and a B-cell genotype based on the presence of clonal immunoglobulin gene rearrangement. ${ }^{15}$ Furthermore, in contrast to most AIDS related, B-cell non-Hodgkin's lymphomas, the AIDS related BCBLs usually contain EBV and consistently lack c-myc gene rearrangements.

Multicentric Castleman's disease, also called multicentric angiofollicular lymphoid hyperplasia, is an atypical lymphoproliferative disorder defined using clinical and pathological characteristics. It is considered to be a polyclonal lymphoid proliferation with vascular hyperplasia and involves multiple lymphoid organs. Severe systemic signs are frequently observed, and there is an increased incidence of lymphoma and Kaposi's sarcoma (occurring in $18 \%$ and $13 \%$ of cases, respectively). ${ }^{14}$ Interestingly, both cutaneous and nodal forms of Kaposi's sarcoma have been associated with this disease. Similar clinical and pathological features of MCD have been found in HIV infected patients with lymph node hyperplasia. In addition, there is a strong association between Kaposi's sarcoma and MCD in HIV infection, where $75 \%$ of patients with MCD subsequently develop Kaposi's sarcoma.

HHV8 sequences have also been found in a high proportion of semen samples from homosexuals, ${ }^{16}$ raising the possibility of viral sexual transmission, as well as prostatic tissue and human semen samples from non-HIV infected individuals. ${ }^{17}$ However, this latter finding has not been confirmed by others. ${ }^{18} 19$

Although Rady et $a l^{20}$ have documented the presence of HHV8 in post-transplant skin lesions, including squamous carcinomas, other groups, including our own, have disputed this. $^{2122}$

\section{HHV8 in Kaposi's sarcoma}

In Kaposi's sarcoma lesions, HHV8 infects spindle and endothelial cells, as demonstrated by PCR in situ hybridisation (PCR-ISH), and the majority of these cells seem to be latently infected. ${ }^{23}$ Viral DNA is generally absent from non-Kaposi's sarcoma tumours and other tissue specimens from individuals lacking Kaposi's sarcoma risk factors. However, viral DNA can be found in circulating B cells in approximately $50 \%$ of AIDS patients with and $7 \%$ of AIDS patients without Kaposi's sarcoma. ${ }^{25}$ In 1984, Walter et al demonstrated herpes-type virus particles in a Kaposi's sarcoma tumour specimen by electron microscopy, but were unaware of the importance of their finding. ${ }^{26}$

\section{Cell culture and HHV8}

Initially, investigators were unable to detect HHV8 sequences in cell lines derived from Kaposi's sarcoma samples, which cast doubt on the significance of HHV8 in its pathogenesis. Nikoloff $e t$ al have now successfully established tumour cell lines from Kaposi's sarcoma lesions, in which HHV8 can be isolated and propagated under certain defined conditions. ${ }^{27}$ This is an important development as the ability to grow HHV8 permits experimentation to determine whether HHV8 is directly capable of causing Kaposi's sarcoma, or whether the presence of other co-factors, such as HIV I, cytokines or some undefined cellular factor, is required. In addition, the propagation of HHV8 in vitro is an extremely important step in providing necessary viral antigens for use in immunoassays (see later).

In 1996, Renne et al demonstrated HHV8 virion production by activated BCBL cells (BCBL I) stimulated by phorbol esters. ${ }^{28}$ They were also able to visualise HHV8 virions in cell lysates from such lymphomatous cells. However, as early as 1972 these virions may have been visualised by Giraldo et al. ${ }^{29}$

\section{Serology and seroepidemiology of HHV8}

Recently, Kedes et $a l^{30}$ and Gao et $a l^{31}$ provided the first evidence of direct seroprevalence of HHV8 and its distribution in Kaposi's sarcoma risk groups. Kedes et al, using an immunofluorescence assay which detects antibodies directed against latency associated nuclear antigens (LANA) in B cells latently infected with HHV8, examined serum samples of 913 patients from different Kaposi's sarcoma risk population cohorts. Their results showed that HHV8 is not a ubiquitous infection in the general population, which contrasts clearly with the known properties of other herpes viruses (such as EBV) in that they infect a relatively large proportion and remain in a latent state throughout the life of the host.

HHV8 seropositivity is high in AIDS patients with Kaposi's sarcoma and in HIV positive homosexual men without Kaposi's sarcoma. ${ }^{30}$ However, HHV8 seroprevalence in 
Table 1 Summary of seroepidemiology of HHV8

\begin{tabular}{|c|c|c|c|c|}
\hline Reference & Cell lines & Assay & Kaposi's sarcoma subtypes (\% positive HHV8) & Controls (\% positive HHV8) \\
\hline Moore $e t a l^{6}$ & HBL-6 (adsorbed serum) & IFA & $\begin{array}{l}\text { Higher in AIDS related KS (14) versus } \\
\text { controls (16) }\end{array}$ & \\
\hline Kedes et a ${ }^{\beta 0}$ & $\begin{array}{l}\text { BCBL-1 cells } \\
\text { LANA }\end{array}$ & IFA & $37 / 45$ AIDS related $\mathrm{KS}(82 \%)$ & $\begin{array}{l}\text { STD-HIV negative }(8 \%) \\
\text { HIV positive blood donors }(30 \%) \\
\text { ( } 83 \% \text { homosexual) } \\
\text { HIV positive haemophiliacs }(3 \%)\end{array}$ \\
\hline Gao et $a l^{\beta 1}$ & $\begin{array}{l}\text { BCP-1 cells } \\
\text { LNA }\end{array}$ & $\begin{array}{l}\text { IFA } \\
\text { Immunoblot }\end{array}$ & $\begin{array}{l}\text { AIDS related KS (US) } 88 \% \\
\text { AIDS related KS (Italy) } 71 \% \\
\text { AIDS related KS (Uganda) } 78 \% \\
\text { HIV negative KS (Italy) } 100 \% \\
\text { HIV negative KS (Uganda) } 100 \%\end{array}$ & $\begin{array}{l}\text { HIV negative haemophiliacs (US) } 0 \% \\
\text { Blood donors (US) } 0 \% \\
\text { Blood donors (Italy) } 4 \%\end{array}$ \\
\hline Gao et $a l^{\beta 2}$ & $\begin{array}{l}\text { BC-1 cells } \\
\text { Latent nuclear antigen } \\
\text { doublet (p226/p234) }\end{array}$ & Immunoblot & $\begin{array}{l}32 / 40(80 \%) \text { AIDS related KS (homosexual) } \\
2 / 2 \text { patients resolved KS }\end{array}$ & $\begin{array}{l}\text { HIV positive homosexual }(18 \%) \\
\text { HIV positive haemophiliac }(0 \%) \\
\text { blood donors }(0 \%) \\
\text { high EBV titres }(0 \%)\end{array}$ \\
\hline Miller et $a l^{47}$ & $\begin{array}{l}\text { BC-1 cells; n-butyrate } \\
\text { inducible antigen ( } p 40)\end{array}$ & IFA & $32 / 48$ AIDS related $\mathrm{KS}(67 \%)$ & $7 / 54(13 \%)$ HIV positive \\
\hline Lennette et al ${ }^{88}$ & $\begin{array}{l}\text { BCBL-1 cells } \\
\text { lytic and latent antigens }\end{array}$ & IFA & $\begin{array}{l}\text { American }(96 \%) \\
\text { African }(100 \%) \\
\text { (lytic antibodies) }\end{array}$ & $\begin{array}{l}\text { HIV positive homosexual }(90 \%) \\
\text { HIV positiveve IVDU }(23 \%) \\
\text { children (US) }(4 \%) \\
\text { Haemophiliacs }(15 \%) \\
\text { Ivory Coast }(100 \%)\end{array}$ \\
\hline Simpson et $a l^{49}$ & $\begin{array}{l}\text { BCP-1 cells } \\
\text { Recombinant ORF } 65 \\
\text { and latent antigens }\end{array}$ & ELISA and IFA & $\begin{array}{l}84 \% \mathrm{KS} \text { (ELISA) } \\
81.5 \% \mathrm{KS} \text { (IFA) }\end{array}$ & $\begin{array}{l}\text { HIV positive homosexual }(33 \%) \\
\text { HIV negative STD }(8.43 \%) \\
\text { HIV negative Ugandan }(35.3 \%) \\
\text { US blood donors }(5 \%) \\
\text { UK donors }(1.6 \%)\end{array}$ \\
\hline
\end{tabular}

HBL-6 and BC-1: lymphoma cell lines (HHV8/EBV positive).

BCBL-1 and BCP-1: lymphoma cell lines (HHV8 positive)

IFA = immunofluorescence assay; ELISA = enzyme linked immunosorbent assay; LANA = latency associated nuclear antigen; LNA = latency nuclear antigen; STD

= sexually transmitted disease; $\mathrm{KS}=$ Kaposi's sarcoma; IVDU = intravenous drug user; ORF = open reading frame.

HIV negative patients with syphilis and in women without sexual exposure (bisexual partners) is low. HIV negative blood donors also have low seroprevalence rates, as do HIV infected haemophiliacs and transfusion recipients $(2-4 \%)$.

Gao et al investigated the seroprevalence of HHV8 in North American, Italian and Ugandan populations, again using indirect immunofluorescence antibody assays. ${ }^{31}$ This was based on the EBV negative, HHV8 infected BCBL cell line, BCP I. The authors detected HHV8 antibodies in approximately $90 \%$ of patients with AIDS associated Kaposi's sarcoma and in $30 \%$ of AIDS patients without Kaposi's sarcoma, which concurred with the study of Kedes et al. Their findings in the Italian cohort were similar. Interestingly, they found high seroprevalence rates $(51 \%)$ in patients without Kaposi's sarcoma in Uganda, which is not surprising in the view of the fact that endemic Kaposi's sarcoma is extremely prevalent in Ugandan locales. In addition, the higher than expected seroprevalence of HHV8 found in the Italian cohort parallels the incidence of classic Kaposi's sarcoma in these regions.

The presence of such specific antibody responses does denote past exposure to HHV8 and may indicate ongoing latent infection. Importantly, Gao et al demonstrated that seroconversion occurred during the adult life of the patients examined. From this seroepidemiological data, it is reasonable to conclude that the distribution of HHV8 does conform epidemiologically to that of a sexually transmissible agent and seems to link itself intimately with the risk of developing Kaposi's sarcoma. This is supported by the documentation of HHV8 seroconversion in a cohort of HIV positive homosexual men prior to the development of overt Kaposi's sarcoma (table 1). ${ }^{32}$

\section{Molecular biology of HHV8}

To establish causation, it is important to demonstrate the presence of HHV8 in patients before they develop Kaposi's sarcoma. This has been demonstrated clearly by the seroprevalence data. However, the presence of HHV8 seropositivity and the presence of HHV8 in Kaposi's sarcoma lesions does not establish a direct role for the virus in the pathogenesis of Kaposi's sarcoma.

Zhong et al have examined the pattern of HHV8 gene expression in Kaposi's sarcoma and found it to be highly restricted. ${ }^{33}$ These authors characterised two small transcripts that represent the bulk of the virus specific RNA, transcribed from over 120 kilobases of the HHV8 genome in infected cells. One of the isolated transcripts is predicted to encode a small membrane protein, whereas the other is an unusual polyadenylated RNA that accumulates in the nucleus in high copy numbers. The pattern of viral gene expression suggests that most infected cells in Kaposi's sarcoma are latently infected and that lytic viral replication is likely to be restricted to a much smaller subpopulation of cells.

Clearly, many factors are involved in the pathogenesis of Kaposi's sarcoma. It is known that several cytokines acting in an autocrine/ paracrine manner play a direct role in the pathogenesis of Kaposi's sarcoma. Cultured Kaposi's sarcoma cells secrete and require certain cytokines, including basic fibroblast growth factor (bFGF), interleukin 6 (IL6) and platelet derived growth factor (PDGF) ${ }^{34}{ }^{35} \mathrm{In}$ addition, mRNA from IL6 and PDGF $\beta$ receptor, PDGP $\alpha$, and PDGF $\beta$ are expressed in high quantities in Kaposi's sarcoma lesions in vivo. It is also interesting that Ensoli et al have demonstrated that HIV contributes to the intitial proliferation of endothelial cells. They have also shown that the Tat protein of HIV I can 


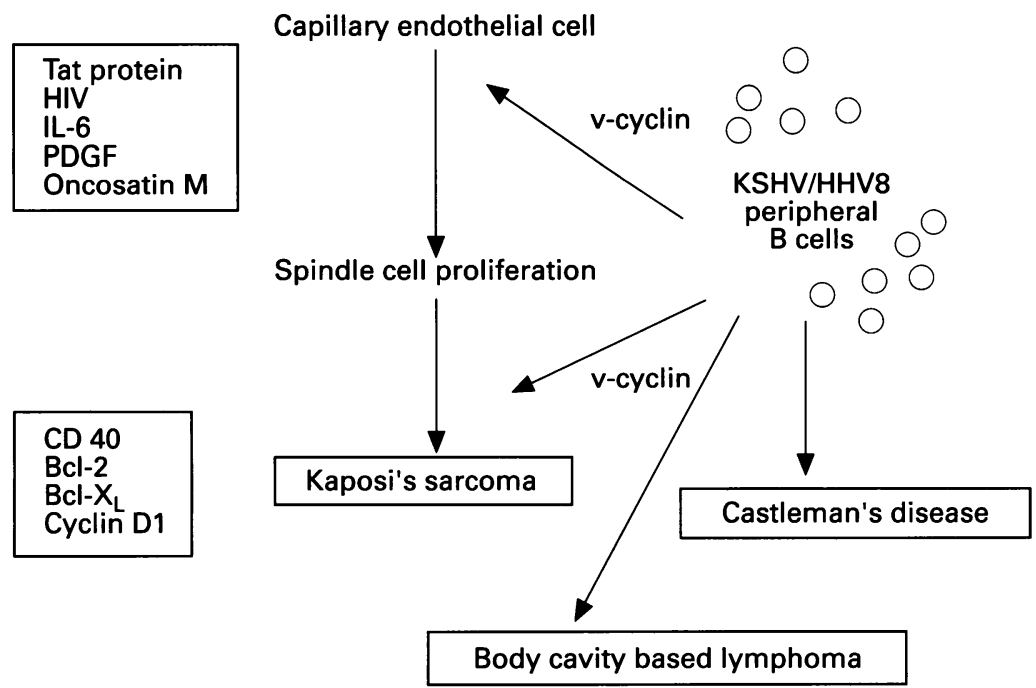

Figure 3 Possible role of HHV8 in Kaposi's sarcoma, BCBL and Castleman's disease. CD 40, cyclin D1, bcl- $x$, and bcl-2 are up regulated in Kaposi's sarcoma, suggesting possible interaction with HHV8. The v-cyclin gene (ORF 72 of HHV8) may act as a cell growth factor/oncogene. as an anti-apoptotic protein, are known to protect virally infected cells from apoptosis.

\section{What is the role of HHV8 in the}

\section{development of Kaposi's sarcoma?}

What is the role of HHV8 in the pathogenesis of Kaposi's sarcoma or BCBL or MCD? There are four possible modes of action.

1 HHV8 may not be oncogenic, but may infect specific $B$ cells that proliferate and respond to developing malignancy, be this Kaposi's sarcoma or BCBL. If this is true, then HHV8 should be detected in serological tests, as demonstrated by Kedes et al and Gao et al. However, its apparent restriction to patients with Kaposi's sarcoma, BCBL and MCD, and absence in other tumour groups tends to contradict this hypothesis.

2 HHV8 infected B cells may have an indirect role in certain defined malignancies, such as Kaposi's sarcoma and BCBL, by enhancing the initial transforming event. A similar promoting role for EBV in some lymphomas (many of which contain EBV) has been suggested, but this effect would seem to be rather specific and tumour restrictive.

3 HHV8 infected B cells may produce cytokines initially causing proliferation of resting endothelial cells, which then promotes transformation/differentiation into the spindle cell phenotype classically seen in Kaposi's sarcoma. Such cytokine production may also be involved in the pathogenesis of BCBL and MCD.

4 HHV8 is involved directly in the proliferation of endothelial cells with activation of endothelial cells and differentiation to spindle cell morphology, and thereby to the formation of Kaposi's sarcoma. This may be mediated by specific cytokines and proteins involved in apoptosis and anti-apoptosis and/or specific gene products involved in cell division. Alternatively, HHV8 may interact with an undefined cellular factor. Sequence analysis of HHV8 has identified several viral genes which are homologous to genes encoding cell cyclins and some $\mathrm{G}$ protein coupled receptors. ${ }^{38}$ Interestingly, HHV8 shares a v-cyclin gene with HVS, which seems to code for a cyclin similar to cyclin D1. ${ }^{39}{ }^{40}$ IL6 coding regions have also been identified. These and other as yet undefined sequences may provide HHV8 with direct oncogenic ability.

In conclusion, we believe that there is increasing evidence $e^{58-121622-2430-3241-49}$ to suggest that HHV8 may be the transmissible infectious agent for Kaposi's sarcoma and, by acting in synergy with other cytokines or by the expression of viral genes or cellular sequences, is intimately involved in the pathobiology of Kaposi's sarcoma.

Kaposi M. Idiopathic multiple pigmented sarcoma of the skin [English Clin skin. [English translation, CA-A Cancer f Clin 2 Rabkin CS, Bedig G, Musaba E, Sunkatu R, Muransa N, Sidransky D, et al. AIDS related Kaposi's sarcoma is a clonal neoplasm. Clin Cancer Res 1995;1:257-60.

3 Morfeldt L, Torssander J. Long term remission of Kaposi's sarcoma following Foscarnet treatment. Scand $\mathcal{F}$ Infect Dis 1994;26:749-52.
Indeed, it is known that EBV-LMP-1 can result in increased expression of CD40. Is it possible that HHV8 acts in an analogous manner? In addition, other EBV gene products, including LMP-1, which induces bcl-2 expression in $\mathrm{B}$ cells, and bhrf-1, which can function 
4 Beral V. Epidemiology of Kaposi's sarcoma. Cancer Surv 1991;10:5-22.

5 Chang Y, Cesarman E, Pessin MS, Lee F, Culpepper J Knowles DM, et al. Identification of herpes-like DNA sequences in AIDS-associated Kaposi's sarcoma. Science 1994;266: 1865-9.

6 Moore PS, Gao S-J, Dominguez G, Cesarman E, Lungu O, Knowles DM, et al. Primary characterization of a herpesvirus agent associated with Kaposi's sarcoma. 7 Virol rus agent associat

7 O'Leary JJ. Seeking the cause of Kaposi's sarcoma. Nat Med 1996;2:862-3

8 Moore PS, Chang Y. Detection of herpesvirus-like DNA sequences in Kaposi's sarcoma in patients with and those without HIV infection. $N$ Engl f Med 1995;332:1181-5.

9 Collandre H, Ferris S, Grau O, Montagnier L, Blanchard A. Kaposi's sarcoma and new herpesvirus. Lancet 1995;345: 1043.

10 Boshoff C, Whitby D, Hatziioannou T, Fisher C, van der Walt J, Hatzakis A, et al. Kaposi's-sarcoma-associated herpesvirus in HIV-negative Kaposi's sarcoma. Lancet 1995; pesvirus in

11 Schalling M, Ekman M, Kaaya EE, Linde A, Biberfeld P. A role for a new herpes virus (KSHV) in different forms of Kaposi's sarcoma. Nat Med 1995;1:707-8.

12 Noel JC. Kaposi's sarcoma and KSHV. Lancet 1995;346: 1359.

13 Cesarman E, Chang Y, Moore PS, Said JW, Knowles DM Kaposi's sarcoma-associated herpesvirus-like DNA sequences in AIDS-related body-cavity-based lymphomas. $N$ Engl F Med 1995;332:1186-91.

14 Soulier J, Grollet L, Oksanhandler E, Cacoub P, CazaleHatem D, Babinet P, et al. Kaposi's sarcoma-associated herpevirus-like DNA sequences in multicentric Castleman's disease. Blood 1995;86:1276-80.

15 Ansari MQ, Dawson DB, Nador R, Rutherford C, Schneider NR, Latimer MJ, et al. Primary body cavitybased AIDS-related lymphomas. Am f Clin Pathol 1996; 105:221-9.

16 Lin J-C, Lin-S-C, Mar E-C, Pellett PE, Stamey FR, Stewart JA, Spira TJ. Is Kaposi's-sarcoma-associated herpesvirus detectable in semen of HIV-infected homosexual men? Lancet 1995;346:1601-2.

17 Monini P, de Lellis L, Fabris M, Rigolin F, Cassai E. Kaposi's sarcoma-associated herpesvirus DNA sequences in prostate tissue and human semen. N Engl F Med 1996;334: $1168-72$

18 Corbellino M, Bestetti G, Galli M, Parravicini C. Absence of HMV-8 in prostate and semen. $N$ Engl f Med 1996;335 1237.

19 Tasaka T, Said JW, Koeffler HP. Absence of HMV-8 in prostate and semen. N Engl F Med 1996;335:1237-8

20 Rady P, Yen A, Rollefson JL, Orengo I, Bruce S, Hughes TK, Tyring SK. Herpesvirus-like DNA sequences in nonKaposi's sarcoma skin lesions of transplant patients. Lancet Kaposi's sarcoma skin

21 Boshoff C, Talbot S, Kennedy M, O'Leary J, Schulz T, Chang Y. HHV8 and skin cancers in immunosuppressed patients. Lancet 1996;347:338-9.

22 Dictor M, Rambech E, Way D, Witte M, Bendsoe N Human Herpesvirus 8 (Kaposi's sarcoma associated herpesvirus) DNA in Kaposi's sarcoma lesions, AIDS Kaposi's sarcoma cell lines, endothelial Kaposi's sarcoma simulators, and the skin of immunosuppressed patients. Am $¥$ Pathol 1996;148:2009-16.

23 Boshoff C Schulz TF, Kennedy M, Graham AK, Thomas A Fisher C, et al. Kaposi's sarcoma-associated Herpesvirus infects endothelial and spindle cells. Nat Med 1995;1: 1274-8.

$24 \mathrm{Li} \mathrm{JJ}$, Huang YQ, Cockerell CJ, Friedman-Kien AK. Localization of human herpes-like virus type 8 in vascula endothelial cells and perivascular spindle-shaped cells of Kaposi's sarcoma lesions by in situ hybridization. $A m \mathcal{F}$ Pathol 1996;148:1741-8.

25 Whitby D, Howard MR, Tenant-Flowers M, Brink NS Copas A, Boshoff C, et al. Detection of Kaposi's sarcoma associated herpesvirus in peripheral blood of HIV-infected individuals and progression to Kaposi's sarcoma. Lancet 1995;346: 799-802.

26 Walter PR, Philippe E, Nguemby-Mbina C, Chamlian A. Kaposi's sarcoma: Presence of Herpes-type virus particles in a tumor specimen. Hum Pathol 1984;15:1145-6.

27 Nickoloff BJ, Foreman KE. Charting a new course through the chaos of KS (Kaposi's sarcoma). Am $\mathcal{F}$ Pathol 1996;148: 1323-9.
28 Renne R, Zhong W, Herndier B, McGrath M, Abbey N, Kedes D, et al. Lytic growth of Kaposi's sarcoma-associated herpesvirus (human herpesvirus 8) in culture. Nat Med 1996;2:342-6.

29 Giraldo G, Beth E, Hagenau F. Herpes-type virus particles in tissue culture of Kaposi's sarcoma from different geographic regions. 7 Natl Cancer Inst 1972;49:1509-29.

30 Kedes DH, Operskalski E, Busch M, Kohn R, Flood J Ganem D.The seroepidemiology of human herpesvirus 8 (Kaposi's sarcoma-associated herpes virus): distribution of (Kaposi's sarcoma-associated herpes virus): distribution of
infection in KS risk groups and evidence for sexual infection in KS risk groups and evide
transmission. Nat Med 1996;2:918-24.

31 Gao S-J, Kingsley L, Li M, Zheng W, Parravicini C, Zeigle J, et al. Seroprevalence of Kaposi's sarcoma-associated herpes virus antibodies among North American and Italian with and without Kaposi's sarcoma. Nat Med 1996;2:925-8.

32 Gao S-J, Kingsley L, Hoover DR, Spira TJ, Rinaldo CR, Saah A, et al. Seroconversion to antibodies against Kaposi's sarcoma-associated herpesvirus-related latent nuclear antigens before the development of Kaposi's sarcoma. $N$ Engl f Med 1996;335:233-41.

33 Zhong E, Wang H, Herndier B, Ganem D. Restricted expression of Kaposi's sarcoma-associated herpesvirus human herpesvirus 8) genes in Kaposi's sarcoma. Proc Natl Acad Sci USA 1996;93:6641-6.

34 Sturzl M, Roth WK, Brockmeyer NH, Zietz C, Speiser B, Hofschneider PH. Expression of platelet-derived growth factor and its receptor in AIDS-related Kaposi's sarcoma in vivo suggests paracrine and autocrine mechanisms of vivo suggests paracrine and autocrine mechanisms of tumour

35 Miles SA, Rezai AR, Salazar-Gonzalez JF, Meyden MV Stevens RH, Logan DM, et al. AIDS Kaposi's sarcomaderived cells produce and respond to interleukin 6. Proc Natl Acad Sci USA 1990;87:4068-72.

36 Ensoli B, Gendelman R, Markham P, Fiorelli V, Colombin $\mathrm{S}$, Raffield $\mathrm{M}$, et al. Synergy between basic fibroblas growth factor and HIV-1 tat protein in induction of Kaposi's sarcoma. Nature 1994;371:674-80.

37 Pammer J, Plettenberg A, Weninger W, Diller B, Mildner M Uthman A, et al. CD40 antigen is expressed by endothelia cells and tumor cells in Kaposi's sarcoma. Am $\mathcal{f}$ Patho 1996;148: 1387-96

38 Motokura T, Arnold A. Cyclins and oncogenesis. Biochim Biophys Acta 1993;1155:63-78.

39 Nicholas J, Cameron KR, Honess RW. Herpesvirus saimiri encodes homologues of $G$ protein-coupled receptors and cycling. Nature 1992;355:362-5.

40 Chang Y, Moore PS, Talbot SJ, Boshoff CH, Zarkowsa T, Godden-Kent D, et al. Cyclin encoded by KS herpes virus. Nature 1996;382:410.

41 Ambroziak JA, Blackbourn DJ, Herndier BG, Glogau RG Gullett JH, McDonald AR, et al. Herpes-like sequences in HIV-infected and uninfected Kaposi's sarcoma patients. Science 1995;268:582-3.

42 Huang YQ, Li JJ, Kaplan MH, Poiesz B, Katabira E, Zhan WC, et al. Human herpesvirus-like nucleic acid in various forms of Kaposi's sarcoma. Lancet 1995;345:759-61.

43 Lebbe C, de Cremoux P, Rybojad M, Costa da Cunha C, Morel P, Calvo F. Kaposi's sarcoma and new Herpesvirus. Lancet 1995;345:1180.

44 Rady PL, Yen A, Martin RW, Nedelcu I, Hughes TK, Tyring SK. Herpesvirus-like DNA sequences in classic Kaposi's sarcomas. F Med Virol 1995;47:179-83.

45 Chang Y, Ziegler J, Wabinga H, Katangole-Mbidde, Boshoff C, Schulz T, et al. Kaposi's sarcoma-associated Herpesvirus and Kaposi's sarcoma in Africa. Arch Intern Med 1996;156: 202-4

46 Moore PS, Kingsley LA, Holmberg SD, Spira T, Gupta P, Hoover DR, et al. Kaposi's sarcoma-associated herpesvirus infection prior to onset of Kaposi's sarcoma. AID 1996;10:175-80

47 Miller G, Rigsby MO, Heston L, Grogan E, Sun R, Metroka $\mathrm{C}$, et al. Antibodies to butyrate-inducible antigens of Kaposi's sarcoma-associated herpesvirus in patients with HIV-1 infection. N Engl ₹ Med 1996;334:1292-7.

48 Lennette ET, Blackbourn DJ, Levy JA. Antibodies to huma herpesvirus type 8 in the general population and in Kaposi's sarcoma patients. Lancet 1996;348:858-61.

49 Simpson GR, Schultz TF, Whitby D, Cook PM, Boshoff C, Rainbow L, et al. Prevalence of Kaposi's sarcoma associated herpesvirus infection measured by antibodies to recombinant capsid protein and latent immunofluoresence antigen. Lancet 1996;348:1133-8. 